\title{
Childhood psoriasis
}

\section{Łuszczyca wieku dziecięcego} Dorota Piekarska-Myślińska', Aldona Pietrzak', Wojciech Myśliński', Daniel Pietrzak', Magdalena Borysowicz²,
Mateusz Socha', Dorota Krasowska'

\author{
'Department of Dermatology, Venereology and Paediatric Dermatology, Medical University of Lublin, Poland \\ 2 Mazovian Specialist Hospital, Radom, Poland \\ ${ }^{3}$ Department of Internal Disease and Cardiology, I Military Clinical Hospital with Polyclinic, Lublin, Poland \\ 'Katedra Dermatologii, Wenerologii i Dermatologii Dziecięcej, Uniwersytet Medyczny w Lublinie, Polska \\ 2Mazowiecki Szpital Specjalistyczny w Radomiu, Polska \\ ${ }^{3}$ Klinika Chorób Wewnętrznych i Kardiologii, I Wojskowy Szpital Kliniczny z Polikliniką w Lublinie, Polska
}

\section{CORRESPONDING AUTHOR/} ADRES DO KORESPONDENCJI: dr hab. n. med. Aldona Pietrzak Katedra Dermatologii, Wenerologii i Dermatologii Dziecięcej Uniwersytet Medyczny ul. Radziwiłłowska 13 20-080 Lublin, Polska tel.: +48 607305501 e-mail: aldonkapietrzak@o2.pl

\begin{abstract}
Psoriasis is a long-lasting inflammatory skin disease with an autoimmunological and immunometabolic background. The latest European data indicate that the occurrence of psoriasis in children ranges from $0.7 \%$ to $2.1 \%$. Despite distinct clinical characteristics, this disease continues to cause diagnostic difficulties and is often incorrectly diagnosed. The goal of this article is to present the course of psoriasis in children, basic diagnostic techniques, including dermoscopy, influence of the disease on the quality of life and risk of co-morbidity development. The therapeutic approcach to childhood psoriasis is presented.
\end{abstract}

\section{STRESZCZENIE}

Łuszczyca jest przewlekłą chorobą zapalną skóry o podłożu autoimmunologicznym i immunometabolicznym. Według najnowszych danych europejskich zapadalność na łuszczycę u dzieci wynosi 0,7-2,1\%. Pomimo charakterystycznego obrazu klinicznego schorzenie to nadal sprawia trudności diagnostyczne i bywa mylone z innymi chorobami. Celem niniejszej pracy jest omówienie odmienności przebiegu łuszczycy u dzieci, podstaw diagnostyki z uwzględnieniem obrazu dermatoskopowego, wpływu na jakość życia i sferę emocjonalną, zagrożenia rozwojem innych chorób, zwłaszcza dziecięcego zespołu metabolicznego oraz odmienności stosowanych metod terapeutycznych.

Key words: psoriasis, epidemiology, children, treatment.

Słowa kluczowe: łuszczyca, epidemiologia, dzieci, leczenie. 


\section{INTRODUCTION}

Psoriasis is a chronic, noncommunicable inflammatory skin disease with an autoimmune and immunometabolic background $[1,2]$. Parisi et al. estimate that there are 125 to 180 million people with psoriasis worldwide with prevalence of $2-8.5 \%$ in Europe and the US [3]. The Polish Dermatology Society estimates psoriasis prevalence in Poland at 1.5-2.8\% [4].

Psoriasis accounts for around $4 \%$ of all skin diseases diagnosed in patients under 16 [2]. Between 1970 and 2000 , the incidence of childhood psoriasis increased more than twofold (from 29.6 to 62.7/100 000) [5]. Stress, infections, increased obesity rate, and genetic factors have been named as the causes [6]. Childhood psoriasis is more common in girls than in boys $[7,8]$ and an early onset might be predictable of a more severe course of the disease. Despite the distinctive clinical characteristics, it may pose a diagnostic challenge and might be incorrectly diagnosed as other skin pathologies [1].

The prevalence of psoriasis in children is estimated at $0.7-2.1 \%[1,3,5,6]$ and shows geographical diversity. Population studies report the highest values in Italy (2.1\%), Germany $(1.3 \%)$ and the UK $(1.3 \%$ in children aged 10-19 years). The lowest prevalence has been observed in Taiwan $(0 \%)$ and Egypt $(0.05 \%)$. Augustin et al. report that the prevalence of the disease increases linearly with age [9]. Childhood psoriasis is more often diagnosed after puberty $(0.6-13 \%)$ than before $(0.1-0.5 \%)$ [6].

Research indicates that genetic factors play a role in the pathogenesis of the disease. Benoit et al. report that in identical twins, psoriasis affects both twins in $65-70 \%$ of cases, and in fraternal twins, in $15-20 \%$ of cases. In nearly $50 \%$ of the children studied, psoriasis was also found in first-degree relatives [10]. It is estimated that when psoriasis exists in one parent, there is a 15\% risk that the disease will develop in the children The risk increases to about $75 \%$ if both parents have the disease [9-11]. If psoriasis develops in a child whose parents are psoriasis-free, there is a $20 \%$ risk that the child's siblings will also develop the disease.

\section{FACTORS TRIGGERING PSORIATIC LESION OUTBREAKS}

Psoriatic outbreaks in children are believed to be triggered most commonly by upper respiratory tract infections (streptococcal infection - $\beta$-hemolytic group A, B, and D; herpes simplex, varicella, herpes zoster viruses). Other factors that may stimulate acute outbreaks or exacerbate chronic disease include yeast-like infections with the fungi Candida albicans and Malassezia; the bacteria Pseudomonas, Klebsiella, and Bacillus cereus; HIV; helminthias-

\section{WSTĘP}

Łuszczyca jest przewlekłą, niezakaźną chorobą zapalną skóry o podłożu autoimmunologicznym i immunometabolicznym [1, 2]. Parisi i wsp. szacują, że dotyczy ona 125-180 milionów ludzi na świecie i ok. 2-8,5\% populacji w USA i Europie [3]. Polskie Towarzystwo Dermatologiczne ocenia zachorowalność na łuszczycę w Polsce na 1,5-2,8\% [4].

Łuszczyca stanowi ok. 4\% wszystkich chorób skórnych rozpoznawanych do 16. roku życia [2]. Zapadalność na łuszczycę u dzieci między 1970 i $2000 \mathrm{r}$. wzrosła ponaddwukrotnie - z 29,6 do 62,7 na 100000 [5]. Jako przyczynę wymienia się: stres, infekcje, zwiększony wskaźnik otyłości oraz uwarunkowania genetyczne [6]. Łuszczyca dziecięca występuje częściej u dziewcząt niż u chłopców [7, 8], a wczesny początek choroby może prognozować jej ciężki przebieg. Pomimo charakterystycznego obrazu klinicznego zdarza się, że powoduje trudności diagnostyczne i jest mylona $z$ innymi chorobami skóry [1].

Zapadalność na łuszczycę u dzieci szacuje się na $0,7-2,1 \%[1,3,5,6]$ i jest zróżnicowana pod względem geograficznym. $W$ badaniach populacyjnych najwyższą zapadalność stwierdzono we Włoszech (2,1\%), Niemczech $(1,3 \%)$ oraz Wielkiej Brytanii (1,3\% dla dzieci w wieku 10-19 lat). Najniższą zapadalność odnotowano na Tajwanie ( $0 \%$ ) oraz w Egipcie ( $0,05 \%)$. Augustin i wsp. zaobserwowali, że częstość występowania choroby wzrasta linijnie z wiekiem [9]. Łuszczyca wieku dziecięcego częściej rozpoznawana jest po okresie dojrzewania $(0,6-1,3 \%)$ niż przed tym okresem $(0,1-0,5 \%)$ [6].

$\mathrm{W}$ patogenezie łuszczycy odgrywają rolę czynniki genetyczne. Benoit i wsp. opisali współwystępowanie łuszczycy u 65-70\% bliźniąt jednojajowych i u 15-20\% bliźniąt dwujajowych. U niemal połowy dzieci stwierdzono przypadki łuszczycy u krewnych pierwszego stopnia [10]. Szacuje się, że w przypadku jednego rodzica chorującego na łuszczycę istnieje 15-procentowe prawdopodobieństwo, że wystąpi ona u potomstwa, jednak gdy obydwoje rodzice mają łuszczycę, to ryzyko wzrasta do ok. 75\% [9-11]. Jeżeli natomiast u dziecka rozwinie się łuszczyca, gdy żadne z rodziców na nią nie choruje, to istnieje 20-procentowa szansa, że rodzeństwo również zapadnie na łuszczycę.

\section{CZYNNIKI PROWOKUJACE WYSIEW ŁUSZCZYCY}

Za najczęstszą przyczynę wysiewu zmian łuszczycowych u dzieci uważa się infekcje górnych dróg oddechowych (zakażenie paciorkowcowe grupy A, $\beta$-hemolizujące B i D, opryszczkę, ospę wietrzną, półpasiec). Inne drobnoustroje, które mogą stymulować ostry wysiew luszczycy lub powodować zaostrzenie postaci przewlekłej, to grzyby drożdżopodobne z rodzaju Candida albicans, drożdżaki z grupy Malassezia, 
es; and caries. Therefore, in the treatment process, sources of infection should be eliminated, and in the case of recurrent tonsillitis, tonsillectomy should be considered [12]. Stress is a strong triggering factor, causing cutaneous lesion outbreaks in $40-80 \%$ of psoriasis patients $[5,6]$.

In children, medication is one of the less important lesion-inducing factors. Other psoriatic lesion triggers include physical factors, such as abrasions, infection, tattooing, vaccinations, insect bites, or burns. The appearance of psoriatic lesions at the site of skin injury in a psoriasis patient is known as the isomorphic response, or Koebner phenomenon $[6,8]$.

\section{CLINICAL PRESENTATION TYPES AND DIFFERENCES}

Psoriasis severity in children and adults is diagnosed similarly. A mild psoriasis diagnosis is given when less than $3 \%$ of the body surface area is affected, for moderate psoriasis the spread is between $3 \%$ and $10 \%$, and for severe psoriasis $10 \%$ or more of the body surface is affected [13].

The psoriasis subtypes in children and adults are the same, though the cutaneous lesions may have different distribution and morphology. Compared to the adult population, in children the lesions are more often observed on the face and auricles; especially common sites affected by the disease are eyelids, and intertriginous areas such as those between the buttocks, near the umbilicus, armpits, groins and genitals $[8,10,14]$.

The typical lesion presentation includes visibly demarcated, scaling red patches that appear periodically and subside during remissions; depending on disease severity, these lesions may affect nearly the whole body surface area or just small portions of the skin $[1,2,7,8]$. In children, the lesions are typically smaller and milder, well-defined, without the typical plaque [10]. The differences in clinical presentation of the disease in children are due to the different structure of the epidermis, including a less developed stratum granulosum and a thin stratum corneum. Hydration of the epidermis and dermis is higher in children than in adults, predisposing the patients to edema [15]. In small children, psoriatic lesions may present as weeping, erythematous-edematous patches. Pruritus is present in most cases. Psoriasis is diagnosed based on the clinical presentation, with histopathological testing and dermoscopic examination used in uncertain cases [15-17].

Matusewicz et al. reported that plaque psoriasis is the most common form of psoriasis in children, a także bakterie z rodzajów Pseudomonas, Klebsiella oraz Bacillus cereus i wirus HIV. Stanami usposabiającymi do wysiewu zmian łuszczycowych są również robaczyce oraz próchnica zębów. W związku z powyższym w postępowaniu terapeutycznym wskazane jest usunięcie ognisk infekcji, a przy nawracającym zapaleniu migdałków należy rozważyć tonsillektomię [12]. Silnym czynnikiem prowokującym jest stres, który powoduje wysiew zmian skórnych u 40-80\% chorych na łuszczycę [5, 6].

Leki jako czynniki indukujące u dzieci mają niewielkie znaczenie. Czynniki fizyczne, takie jak otarcia naskórka, tatuaże, szczepienia, ukąszenia owadów, oparzenia, zalicza się do czynników prowokujących wystąpienie zmian łuszczycowych. Pojawienie się zmian łuszczycowych w miejscu urazu skóry u chorego na łuszczycę określa się jako objaw izomorficzny (objaw Koebnera) [6, 8].

\section{TYPY I ODMIENNOŚCI OBRAZU KLINICZNEGO}

Stopień nasilenia łuszczycy u dzieci określa się podobnie jak $\mathrm{u}$ dorosłych. W postaci łagodnej zmiany obejmują mniej niż 3\%, a w postaci umiarkowanej 3-10\% powierzchni ciała. Zmiany obejmujące powyżej $10 \%$ powierzchni ciała wskazują na łuszczycę o ciężkim przebiegu [13].

Chociaż u dzieci rozpoznaje się te same podtypy łuszczycy co u dorosłych, zmiany skórne mogą różnić się pod względem rozmieszczenia i morfologii. W porównaniu z dorosłymi u dzieci obserwuje się częstsze występowanie zmian na skórze twarzy i małżowin usznych; szczególnie często zajęte są powieki oraz okolice wyprzeniowe pośladków, pępka, pach, pachwin i narządów płciowych $[8,10,14]$.

Typowe zmiany chorobowe stanowią widocznie odgraniczone, złuszczające się, rumieniowe tarczki, które pojawiają się okresowo i ustępują w okresie remisji, zajmując w zależności od stopnia nasilenia prawie całą powierzchnię ciała lub jedynie drobne fragmenty skóry [1, 2, 7, 8]. Zmiany u dzieci są zazwyczaj mniejsze, delikatniejsze, dobrze odgraniczone od otoczenia, nie ma charakterystycznej łuski [10]. Odmienności obrazu klinicznego u dzieci należy tłumaczyć odmienną budową naskórka, która polega na słabym wykształceniu warstwy ziarnistej oraz obecności cienkiej warstwy rogowej. W porównaniu z dorosłymi naskórek i skóra właściwa są bardzo uwodnione, co predysponuje do obrzęku [15]. U małych dzieci zmiany łuszczycowe mogą być sączące, mają formę plam rumieniowo-obrzękowych. W większości przypadków występuje świąd. Łuszczycę rozpoznaje się na podstawie obrazu klinicznego, a w wątpliwych przypadkach pomaga badanie histopatologiczne oraz dermatoskopowe [15-17].

Matusewicz i wsp. podają, że najczęstszą postacią łuszczycy u dzieci - podobnie jak u dorosłych - jest łuszczyca plackowata [18]. Drugą co do częstości wy- 
which is similar to the situation in adult patients [18]. The second most common form of psoriasis in children is guttate psoriasis, which is typically linked with a history of streptococcal infection [10]. This from often has a self-limiting course and it occurs more often in younger children, compared with children between the ages of 13 and 18 [8, 10].

Pustular psoriasis is more common in adults, and rarely occurs in children, except for the annular pustular psoriasis and von Zumbusch generalized pustular psoriasis subtypes that manifest more often in the pediatric population $[1,8,10,19]$.

Erythrodermic psoriasis is very rare in children. This form of the disease requires hospitalization and may result in hypoalbuminemia, hypothermia, and subsequent heart failure $[1,8,10]$. Linear psoriasis is an uncommon subtype of psoriasis, typically found in children. In this case lesions may already be present at birth and are very resistant to treatment. The characteristic feature of its presentation is the linear distribution of lesions along Blaschko's lines $[1,8,10]$.

In infants and small children, the most common psoriasis forms include napkin dermatitis, or napkin psoriasis. It presents with sharply demarcated, slightly elevated erythematous lesions in the inguinal fold area. Not all infants with napkin psoriasis develop psoriasis at a later age. This form of psoriasis presents some diagnostic difficulties and requires differential diagnosis with diaper dermatitis, atopic dermatitis, and intertrigo. Diagnostic features include lack of response to classical diaper dermatitis treatment, development of lesions at other sites, or existing psoriasis in other family members $[1,8$, 10]. Inverse psoriasis as well as pustular are more common in infants than in older children and adolescents [14].

Changes affecting nails may be found with all subtypes of psoriasis, and in some cases may be the only manifestation of the disease. They are rarely observed in infants, but more commonly in older children. French researchers have reported nail lesions in approx. $30 \%$ of children with psoriasis (out of 313 children in 23 dermatology centers). Pitting of the nails is most common on fingernails, while onycholysis or thickening is more common on toenails. The big toe is also more predisposed to psoriatic nail lesions, and contributing factors include male sex, palmoplantar psoriasis, severe psoriasis and psoriatic arthritis [21, 22].

\section{PSORIATIC ARTHRITIS}

Though psoriatic arthritis is less common in children than in adults, it accounts for approximately $20 \%$ of all cases of arthritis in children. Typically, it stępowania odmianą łuszczycy u dzieci jest łuszczyca kropelkowata [10]. Jej wystąpienie łączy się zazwyczaj z przebytą infekcją paciorkowcową. Zwykle ma przebieg samoograniczający się. Częściej występuje u dzieci młodszych w porównaniu z dziećmi w wieku 13-18 lat $[8,10]$.

Łuszczyca krostkowa to postać charakterystyczna raczej dla wieku dorosłego, u dzieci opisywana jest zdecydowanie rzadziej. W przeciwieństwie do dorosłych u dzieci łuszczyca krostkowa częściej ma postać obrączkowatą oraz uogólnioną typu von Zumbuscha [1, 8, 10, 19].

Erytrodermiczna postać łuszczycy u dzieci występuje bardzo rzadko. Postać ta wymaga hospitalizacji, może prowadzić do niedoboru albumin, hipotermii oraz wtórnie niewydolności serca $[1,8,10]$. Nietypową formą łuszczycy charakterystyczną dla wieku dziecięcego jest łuszczyca linijna. Zmiany mogą być obecne już od urodzenia i cechują się dużą opornością na leczenie. Charakterystyczny w obrazie klinicznym jest układ wykwitów wzdłuż linii Blaschko $[1,8,10]$.

U niemowląt i małych dzieci często występuje łuszczycowe pieluszkowe zapalenie skóry. Ma postać ostro odgraniczonych, nieznacznie uniesionych zmian rumieniowych, które obejmują fałdy pachwinowe. Nie wszystkie niemowlęta z łuszczycowym pieluszkowym zapaleniem skóry chorują na łuszczycę w wieku późniejszym. Jest to postać sprawiająca pewne trudności diagnostyczne - wymaga różnicowania z pieluszkowym zapaleniem skóry, atopowym zapaleniem skóry, wyprzeniami. Cechę różnicującą stanowi brak odpowiedzi na klasyczne leczenie pieluszkowego zapalenia skóry, wystąpienie zmian w innej lokalizacji, współistnienie łuszczycy u członków rodziny $[1,8,10]$. U niemowląt częściej niż u starszych dzieci i młodzieży spotyka się łuszczycę odwróconą [14].

Zmiany na płytce paznokciowej mogą towarzyszyć każdej postaci łuszczycy, a w niektórych przypadkach mogą stanowić jedyną manifestację choroby. Rzadko są widoczne u niemowląt, częściej u starszych dzieci. Według autorów francuskich zmiany paznokciowe dotyczą ok. 30\% dzieci z łuszczycą (313 dzieci z 23 ośrodków dermatologicznych). W przypadku płytek paznokciowych palców rąk występują w postaci objawu naparstka, na stopach częściej jako onycholiza i zgrubienie paznokci. Predysponowana do zajęcia przez proces łuszczycowy jest płytka paznokciowa palucha, a czynnikami ryzyka wystąpienia zmian paznokciowych są płeć męska, łuszczyca dłoni i stóp, stopień nasilenia choroby oraz łuszczycowe zapalenie stawów [21, 22].

\section{ŁUSZCZYCOWE ZAPALENIE STAWÓW}

Chociaż łuszczycowe zapalenie stawów u dzieci występuje rzadziej niż u dorosłych, stanowi ok. 20\% wszystkich przypadków zapaleń stawów u dzieci. Po raz pierwszy pojawia się zazwyczaj między 7. i 13. 
first appears between the ages of 7 and 13. In roughly $30 \%$ of the patients, arthritis occurs earlier than cutaneous lesions and typically (50\%) affects a single joint. No correlation was found between the severity of skin lesions and arthritis. Occurrence of joint complaints in a child with psoriasis is an indication for urgent rheumatology consultation [23].

\section{LESION DIAGNOSIS}

In most cases, the distribution and presentation of lesions provide a sufficient basis for diagnosis. Skin biopsy may be required in atypical or treatment-resistant cases. Microscopic examination shows epidermal neutrophil clusters (Munro's abscesses), perivascular lymphocyte infiltrations, dilated blood vessels in the dermis, elongated dermal papillae, loss of stratum granulosum and parakeratoses [16]. Histological presentation depends on psoriasis subtype, lesion location, and treatment used (topical or systemic). Before a biopsy is performed, topical treatment should be withheld in order to obtain accurate test results [16].

Dermoscopy is a simple, quick and non-invasive method that may assist in psoriasis diagnosis [17]. Dermoscopic examination of psoriatic lesions shows regularly distributed punctuate vessels consistent with dilated capillaries in regularly distributed dermal papillae. Other findings may include red globules, hairpin vessels, and glomerular vessels, consistent with dilated and elongated capillaries. Dermoscopic alterations are seen in $87-100 \%$ of cases; therefore, the examination should be performed before a biopsy is considered.

\section{PSORIASIS AND QUALITY OF LIFE}

As demonstrated in studies using the Children's Dermatology Life Quality Index (CDLQ) psoriasis reduces quality of life, both in adults and in children $[1,24]$. Psychological studies from the last decade indicate that quality of life in children with moderate or severe psoriasis is similar to that of children with arthritis and asthma and, interestingly, lower than in children with diabetes. Subjective complaints reported by children with psoriasis include pruritus, fatigue, stigmatization, and embarrassment [24]. Other observations include decreased self-esteem, problems functioning in peer groups, and difficulties at school [18]. The chronic skin condition also adversely affects the quality of life of other family members [1, 5, 24-26].

Children with psoriasis are at a higher risk of depression, anxiety and bipolar disorder than healthy children $[26,27]$. In a group of children with psori- rokiem życia. U ok. 30\% pacjentów zmiany stawowe stwierdza się wcześniej niż zmiany skórne i w połowie przypadków obserwuje się zajęcie pojedynczego stawu. Nie wykazano korelacji między nasileniem zmian skórnych i stawowych. Wystąpienie dolegliwości stawowych u dziecka z łuszczycą jest wskazaniem do pilnej konsultacji reumatologicznej [23].

\section{DIAGNOSTYKA ZMIAN}

Lokalizacja oraz rodzaj zmian chorobowych pozwalają w większości przypadków na postawienie diagnozy. Biopsja skóry może być konieczna w przypadkach o nietypowym przebiegu bądź opornych na leczenie. W obrazie mikroskopowym obecne są skupiska neutrofilów w naskórku (ropnie Munro), okołonaczyniowe nacieki z limfocytów, poszerzone naczynia krwionośne w warstwie skóry właściwej, wydłużenie brodawek, utrata warstwy ziarnistej oraz parakeratoza [16]. Obraz histologiczny zależy od rodzaju łuszczycy, lokalizacji zmiany, a także zastosowanego leczenia (miejscowe lub ogólne). Przed podjęciem decyzji o biopsji zaleca się przerwanie leczenia miejscowego w celu uzyskania wiarygodnego wyniku badania [16].

Dermatoskopia jest prostą, szybką i nieinwazyjną metodą diagnostyczną, która może pomóc w rozpoznaniu łuszczycy [17]. W badaniu dermatoskopowym zmian łuszczycowych widoczne są równomiernie rozmieszczone naczynia punkcikowe, odpowiadające rozszerzonym naczyniom włosowatym $\mathrm{w}$ regularnie rozmieszczonych brodawkach skórnych. Mogą być również widoczne czerwone globulki, poskręcane naczynia z wyglądu przypominające spinkę do włosów i naczynia kłębkowate, odpowiadające rozszerzonym i wydłużonym naczyniom włosowatym. Zmiany dermatoskopowe widoczne są w 87-100\% przypadków, warto więc wykonać to badanie przed podjęciem decyzji o biopsji.

\section{ŁUSZCZYCA A JAKOŚĆ ŻYCIA}

Łuszczyca powoduje obniżenie jakości życia zarówno u dorosłych, jak i u dzieci, co wykazano w badaniach z użyciem wskaźnika CDLQ (the Children's Dermatology Life Quality Index) [1, 24]. Badania psychologiczne prowadzone w ostatniej dekadzie wskazują, że jakość życia dzieci z umiarkowaną lub ciężką postacią łuszczycy jest podobna do jakości życia u dzieci cierpiących na zapalenie stawów i astmę. Co ciekawe, poziom ten jest niższy niż $u$ dzieci chorujących na cukrzycę. Subiektywnymi dolegliwościami zgłaszanymi przez dzieci z łuszczycą są świąd skóry, zmęczenie, stygmatyzacja i uczucie zażenowania [24]. Obserwuje się również obniżenie poczucia własnej wartości [18], zaburzenie funkcjonowania w grupie rówieśniczej, trudności szkolne. Przewlekła choroba skóry nega- 
asis, the percentage of children treated with psychiatric medications was $47 \%$ higher than in controls. As such medications are normally administered in severe cases only, the actual prevalence of these disorders may be higher [1].

\section{COMORBIDITIES}

Psoriasis is associated with the development of comorbidities or complications, including obesity, hypertension, hyperlipidemia, metabolic syndrome, diabetes mellitus, Crohn's disease, and rheumatoid arthritis $[1,6,8,9,20]$. Psoriasis in children results in less physical activity, as pruritus intensifies during exercise, and children are reluctant to engage in exercise that would expose their skin lesions. The decreased activity or its total absence may contribute to overweight and obesity [13]. Zhu et al. report that in overweight children, the course of psoriasis is more severe than in their counterparts with normal body weight [28].

Evidence exists indicating an association between pediatric metabolic syndrome and psoriasis in adults [26]. Psoriasis is associated with increased cardiovascular disease in adults, but the risk profile of children with psoriasis remains to be fully characterized.

Recently published data indicate that psoriasis is an independent risk factor for cardiovascular disease among adults. The risk profile for our younger patients is still under investigation, but a pattern linking psoriasis and the metabolic syndrome seems to be emerging $[1,8,9,13,20,28-34]$.

In a study by Tom et al. [34] which included 44 pediatric patients (mean age: 13 years) and 44 healthy controls matching the study group in terms of age and sex, nuclear magnetic resonance spectroscopy and a validated ex vivo assay of high-density lipoprotein cholesterol efflux capacity were used to analyze the composition and function of lipoproteins in the two groups. Psoriatic children presented increased insulin resistance, higher levels of apolipoprotein B and lower levels of high density lipoprotein (HDL). The observed insulin resistance and abnormal composition and function of lipoproteins might constitute proatherogenic factors and at least partially explain the association between psoriasis and cardiovascular diseases later in life.

In 6 out of 7 studies analyzed, children with psoriasis were found to have significantly decreased HDL-C concentrations $(p<0.05)$ [30]. Multiple authors, including Au et al. [31], Koebnick et al. [32], and Volf et al. [33], state that pediatric psoriasis patients should be monitored for cardiovascular risk factors and, if found at risk, should receive preventive interventions [34]. tywnie wpływa na jakość życia pozostałych członków rodziny [1, 5, 24-26].

Ryzyko wystąpienia depresji, stanów lękowych oraz zaburzeń afektywnych dwubiegunowych jest większe u dzieci z łuszczycą niż u zdrowych [26, 27]. U dzieci z łuszczycą obserwowano wyższy o $47 \%$ odsetek przyjmujących leki psychotropowe niż u dzieci bez łuszczycy. Ponieważ leki psychotropowe są zazwyczaj stosowane w ciężkich przypadkach, rzeczywista liczba zaburzeń może być większa [1].

\section{CHOROBY WSPÓŁISTNIEJĄCE}

Łuszczyca wiąże się z rozwojem schorzeń współistniejących lub wikłających jej przebieg, takich jak otyłość, nadciśnienie, hiperlipidemia, zespół metaboliczny, cukrzyca, choroba Leśniowskiego-Crohna i reumatoidalne zapalenie stawów [1, 6, 8, 9, 20]. Obecność łuszczycy u dzieci powoduje mniejszą aktywność fizyczną związaną z nasileniem świądu w czasie wysiłku oraz niechęcią do eksponowania zmian na skórze podczas zajęć sportowych. Mniejsza aktywność fizyczna lub jej brak może prowadzić do nadwagi i otyłości [13]. Zhu i wsp. podają, że przebieg łuszczycy u dzieci z nadwagą jest cięższy niż u ich rówieśników z prawidłową masą ciała [28].

Ostatnio opublikowane badania wskazują, że łuszczyca przyczynia się do wzrostu ryzyka wystąpienia chorób układu krążenia u dorosłych. U pacjentów pediatrycznych profil ryzyka nie został jeszcze w pełni określony, jednak istnieją dane wskazujące na związek między dziecięcym zespołem metabolicznym a łuszczycą $[1,8,9,13,20,28-34]$.

W badaniu Toma i wsp. [34], w którym wzięło udział 44 dzieci chorujących na łuszczycę (średnia wieku 13 lat) oraz 44 zdrowych dzieci stanowiących grupę kontrolną dopasowaną pod względem płci i wieku, wykorzystano spektroskopię magnetycznego rezonansu jądrowego oraz badanie ex vivo zdolności do transportu zwrotnego cholesterolu HDL w celu analizy składu oraz funkcji lipoprotein. U dzieci z łuszczycą stwierdzono zwiększoną insulinooporność, zwiększone stężenie apolipoproteiny B i zmniejszone stężenie lipoprotein o wysokiej gęstości (high density lipoprotein - HDL). Insulinooporność oraz zaburzenia składu i funkcji lipoprotein mogą stanowić czynniki proaterogenne i częściowo przynajmniej wyjaśniać związek między łuszczycą a chorobami układu krążenia w późniejszym wieku.

W 6 z 7 badań zaobserwowano istotnie zmniejszone stężenie HDL-C u dzieci z łuszczycą $(p<0,05)$ [30]. Wielu autorów, takich jak Au i wsp. [31], Koebnick i wsp. [32], Volf i wsp. [33], uważa, że dzieci z łuszczycą powinny być monitorowane w celu identyfikacji czynników ryzyka wystąpienia chorób układu krążenia, a w przypadku ich wykrycia objęte profilaktyką i działaniami edukacyjnymi [34]. 


\section{PSORIASIS TREATMENT IN CHILDREN}

As the disease is chronic and recurrent, effective treatment requires cooperation between the physician, the patient, and the patient's parents. In some cases, other individuals from the patient's social environment, i.e. school or preschool, must be involved as well. The patient's parents must always be educated on the chronic course and phases of the disease, its triggers, proper skin care and topical treatment [9, $14,20,24]$. Other important information includes the possible need for psychological support, regular dental or ENT check-ups, and a balanced diet. As there are no guidelines for treatment, and most (systemic) psoriasis treatment methods have not been approved for use in children, treatment of childhood psoriasis remains a challenge [35-39]. In children, systemic treatments are prescribed more often than in adults, as they are typically better tolerated, produce prompt remissions, and are more consistent with the treatment model.

Psoriasis treatment in children and adolescents needs to be planned individually. The primary goal is to ensure maximum safety and at the same time obtain the best possible outcomes of the regimen used.

When choosing treatment options, the following factors must be considered: patient age, clinical form of psoriasis, location of lesions, disease severity, concurrent psoriatic arthritis, previous treatment, comorbidities, medication availability, possibilities for application (including treatment cost), complication risk analysis, and impact on quality of life (exercise, functional complications, emotional and social factors) [14, 35-39].

Also, anatomical and physiological differences need to be taken into account as penetration and dermal absorption of topical drugs are much better in children and adolescents than in adults $[15,16]$. Utmost caution must be exercised when using steroids, or anthralin, which are often administered to psoriatic patients affected with considerable pruritus. In such cases intermittent treatment often proves effective, e.g. a sequential or interval regime, which should be combined with careful skin protection with emollients, preferably urea-containing products, and moisturizers. Similar caution is advised with regard to salicylic acid due to the considerable risk of adverse side-effects. In pre-school children, especially infants and children below 3 years of age, salicylic acid should only be applied on small areas and at a concentration not exceeding $0.5 \%$ [14, 35-41].

\section{PHOTOTHERAPY}

Phototherapy is typically suitable for children with plaque, guttate or pustular psoriasis, where

\section{LECZENIE ŁUSZCZYCY U DZIECI}

Ze względu na przewlekłość i nawrotowość choroby dla skutecznego leczenia niezbędna jest współpraca na linii: lekarz - rodzice pacjenta - pacjent, a czasem konieczne jest zaangażowanie $\mathrm{w}$ proces terapeutyczny dodatkowo osób ze środowiska, w którym przebywa dziecko, tj. szkoły bądź przedszkola. Należy bezwzględnie przedstawić rodzicom pacjenta problem przewlekłości i fazowości choroby, wskazać czynniki zaostrzające oraz wyedukować w zakresie dbania o skórę i stosowania leków miejscowych [9, 14, 20, 24]. Wskazane jest poinformowanie o możliwej potrzebie wsparcia psychologicznego, konieczności regularnych kontroli stomatologicznych i laryngologicznych oraz włączenie diety o zrównoważonych proporcjach. Ponieważ nie istnieją wytyczne dotyczące terapii, a większość metod leczenia (ogólnego) nie została zaaprobowana do stosowania u dzieci, terapia łuszczycy wieku dziecięcego stanowi wyzwanie [35-39]. U dzieci chętniej niż u dorosłych sięga się po leki ogólne, ponieważ zazwyczaj są lepiej tolerowane, dają szybką remisję i są bardziej akceptowane przez pacjentów.

Terapia łuszczycy u dzieci i młodzieży musi być zaplanowana indywidualnie, a nadrzędnym celem jest zapewnienie najwyższego stopnia bezpieczeństwa przy jednoczesnym uzyskaniu maksymalnej skuteczności stosowanego schematu leczenia. W wyborze terapii łuszczycy należy uwzględnić następujące czynniki: wiek pacjenta, postać kliniczną, lokalizację zmian, ciężkość przebiegu choroby, towarzyszące łuszczycowe zapalenie stawów, poprzednio stosowane terapie, wspólistnienie innych chorób, możliwości aplikacji, dostępność leków (w tym koszty leczenia), analizy ryzyka wystąpienia powikłań, wpływ na jakość życia (aktywność fizyczna pacjenta, powikłania czynnościowe, emocjonalne, społeczne) [14, 35-39].

Powinno się uwzględnić różnice anatomiczne i fizjologiczne, które powodują, że u dzieci i młodzieży w przypadku leków stosowanych miejscowo ich penetracja i wchłanianie przez skórę są znacznie lepsze [15, 16]. Szczególną ostrożność należy zachować w przypadku steroidów czy antraliny, które bardzo często są stosowane w postaciach choroby przebiegających ze znacznym świądem. W takich sytuacjach często dobrze sprawdzają się schematy terapii przerywanej, np. sekwencyjne lub interwałowe, którym powinna towarzyszyć staranna ochrona skóry za pomocą emolientów, najlepiej zawierających mocznik, i preparatów nawilżających. Podobne zalecenia dotyczą stosowania kwasu salicylowego ze względu na duże ryzyko wystąpienia niepożądanych działań ubocznych. Stosowanie go u dzieci przed osiągnięciem wieku szkolnego dopuszczalne jest wyłącznie na małe powierzchnie i w stężeniu nieprzekraczającym $0,5 \%$, zwłaszcza w przypadku niemowląt i dzieci poniżej 3. roku życia [14, 35-41]. 
lesions affect $15-20 \%$ of the body surface area or where systemic medications cannot be used.

The treatment involves the use of narrowband UVB (NB-UVB: 311-313 nm), broadband UVB (BBUVB: $280-320 \mathrm{~nm}$ ), and UVA radiation. Particularly good outcomes of phototherapy have been reported in children with papular and plaque psoriasis. Adverse effects found in the pediatric population include erythema, blistering, dry skin and pruritus. No data are available regarding long-term consequences of phototherapy in children. Further research is warranted, especially with regard to premature skin aging and carcinogenesis.

UVA radiation is used in combination with psoralen, a photosensitizing agent. This method is normally contraindicated in children under 12 years of age due to its adverse effects that include nausea, vomiting, hepatic toxicity, burn risk, and a longterm increase of skin cancer risk $[40,41]$.

\section{SYSTEMIC NON-BIOLOGICAL TREATMENT}

Experience of Polish authors, based on treating a large group of children for more than 25 years, indicates that in the case of pustular psoriasis and psoriatic erythroderma oral retinoids remain the drugs of first choice [39].

Severe cases of plaque psoriasis, pustular psoriasis, erythrodermic psoriasis, and psoriatic arthritis require systemic treatment. Drugs used in children include acitretin, cyclosporin, and methotrexate. None of these medications are approved by the Food and Drug Administration (FDA) for treatment of psoriasis in children due to the lack of randomized trials in this age group. Evidence of risks and benefits of the drugs is derived from their use in other conditions, such as ichthyosis and juvenile arthritis, or in patients after organ transplantations [40,41].

Acitretin is a second-generation retinoid used in younger children as short-term emergency treatment in severe pustular psoriasis, and as long-term treatment in older children with severe plaque, pustular or erythrodermic psoriasis. It shows synergistic effects in combination with UVB 311 phototherapy. It is typically well tolerated by children. During treatment, hepatic function and lipid levels must be monitored. The teratogenic potential of the treatment is considerably less significant in this age group $[1,8,41]$.

Cyclosporin A (CsA) has been approved by the FDA for treatment of children aged 6 months and above after organ transplantations. It is also used in treatment for erythrodermic psoriasis, severe pustular psoriasis, and in cases of psoriasis unresponsive to other treatment, as a short-term (typically 12week) emergency therapy. Onset of the therapeutic

\section{FOTOTERAPIA}

Fototerapia jest zazwyczaj ogólnoustrojowym leczeniem z wyboru u dzieci z łuszczycą plackowatą, kropelkową, krostkową, ze zmianami obejmującymi 15-20\% powierzchni ciała, a także gdy nie mogą być włączone leki ogólne.

W leczeniu stosuje się promieniowanie UVB (wąskopasmowe: NB-UVB 311-313 nm lub szerokopasmowe: BB-UVB 280-320 nm) oraz UVA. Szczególnie korzystne efekty fototerapii obserwowano w przypadkach łuszczycy grudkowej oraz plackowatej u dzieci.

Do działań niepożądanych obserwowanych u dzieci należą: rumień, pęcherze, suchość skóry, świąd. Nie ma danych dotyczących odległych skutków fototerapii u dzieci. Zagadnienie to wymaga dodatkowych badań, zwłaszcza w kwestii przedwczesnego starzenia skóry i kancerogenezy.

Naświetlanie UVA stosuje się w połączeniu z fotouczulającym psolarenem. Jest to metoda zazwyczaj przeciwwskazana u dzieci młodszych niż 12 lat z powodu działań niepożądanych, do których należą nudności, wymioty, hepatotoksyczność, ryzyko oparzeń oraz jako powikłanie odległe - zwiększone ryzyko wystąpienia raka skóry $[40,41]$.

\section{LECZENIE OGÓLNE NIEBIOLOGICZNE}

Doświadczenia polskich autorów oparte na leczeniu dużej grupy dzieci w ciągu ponad 25 lat wskazują, że w przypadku łuszczycy krostkowej i erytrodermii łuszczycowej lekiem z wyboru są doustne retinoidy [39].

Ciężkie przypadki łuszczycy plackowatej, krostkowej, erytrodermicznej oraz łuszczycowe zapalenie stawów wymagają leczenia ogólnego. U dzieci stosuje się nastepujące leki: acytretynę, cyklosporynę, metotreksat. Żaden z tych leków nie ma rejestracji amerykańskiej Agencji ds. Żywności i Leków (Food and Drug Administration - FDA) w leczeniu łuszczycy u dzieci ze względu na brak randomizowanych badań w tej grupie wiekowej. Dane o korzyściach i ryzyku wynikają ze stosowania tych leków w innych jednostkach chorobowych, takich jak rybia łuska i młodzieńcze idiopatyczne zapalenie stawów, a także po transplantacji narządów [40, 41].

Acytretyna jest retinoidem drugiej generacji stosowanym u młodszych dzieci jako krótkotrwała terapia ratunkowa w łuszczycy krostkowej o ciężkim przebiegu oraz w długotrwałej terapii u starszych dzieci z łuszczycą krostkową, erytrodermiczną oraz plackowatą o ciężkim przebiegu. Ma synergistyczne działanie $\mathrm{z}$ fototerapią UVB 311. Na ogół jest dobrze tolerowana przez dzieci. Podczas terapii wymagane jest monitorowanie funkcji wątroby oraz stężenia lipidów. Znacznie mniejsze znaczenie $\mathrm{w}$ tej grupie wiekowej ma jej potencjał teratogenny $[1,8,41]$. 
effect is fast (2-4 weeks). Due to differences in pharmacokinetics, children are administered higher doses of the drug than adults. Drawbacks of cyclosporin treatment include renal toxicity and potential for recurrence once treatment is discontinued; therefore some authors suggest that it should be used in combination with other drugs, or replaced with another medication (e.g. a retinoid) once the acute phase has been controlled. Due to its potential oncogenic effects, it should not be used in combination with phototherapy. When using CsA in children, one must bear in mind that, being an immunosuppressant, it may restrict post-vaccination immunity. Moreover, vaccines containing viable pathogens are contraindicated, and viral childhood diseases can have a more severe course $[1,8,40,41]$.

Methotrexate (MTX) is not recommended for use in children under the age of 3. It is typically used as a short-term treatment for severe plaque psoriasis, erythrodermic psoriasis and psoriatic arthritis. It is typically tolerated better by children than adults. One advantage is the dosing schedule - once weekly. The drug can be used subcutaneously, which limits its adverse impact on the digestive system (nausea, vomiting). Serious adverse events include hepatic toxicity (much less common in children than in adults) $[1,10,20,36,42]$, pulmonary fibrosis (episodic in children), and myelotoxicity. The bone marrow suppression typically occurs in the first 4-6 weeks of treatment. Therefore, some authors recommend starting the treatment at a dose of $1.25 \mathrm{mg}$, later increased up to $5 \mathrm{mg}$ if tolerated well. There are multiple known drug interactions with MTX. For children, the most important ones are nonsteroid anti-inflammatory drugs (NSAIDs) and trimethoprim/ sulfamethoxazole [36, 37] (Table 1).

\section{FUMARIC ACID ESTERS AND APREMILAST}

Fumaric acid esters (FAEs) are immunomodulatory agents, not registered in Poland. In Germany, FAE preparations are available and used for treatment of moderate and severe plaque psoriasis [37]. Studies in children are scarce. A retrospective analysis of 14 patients treated with FAEs showed complete remission in $36 \%$ of cases, clinically significant improvement in $7 \%$, partial improvement in $21 \%$, and no effect in $36 \%$. The mean treatment duration was 10 months (between 1 and 80 months in the group). The starting dose was $30 \mathrm{mg}$ of dimethyl fumarate, later increased (depending on effectiveness and any adverse events) up to the maximum dose of $720 \mathrm{mg}$ daily $[1,43]$. The reported adverse effects included eosinophilia, periodic changes in leukocyte count, erythema, digestive disorders including liver dysfunction with increased hepatic enzyme (aminotransferase) levels, protein-
Cyklosporyna A (CsA) została zarejestrowana przez FDA do leczenia dzieci powyżej 6. miesiąca życia po transplantacji narządów. Znajduje zastosowanie w terapii łuszczycy erytrodermicznej i ciężkich postaci łuszczycy krostkowej oraz w przypadkach nieskutecznej terapii innymi preparatami jako krótkotrwała (zazwyczaj 12 tygodni) terapia ratunkowa. Cechuje się szybkim (2-4 tygodnie) początkiem działania. U dzieci $\mathrm{z}$ powodu różnic $\mathrm{w}$ zakresie farmakokinetyki stosuje się większe dawki leku niż u dorosłych. Do wad CsA należą działanie nefrotoksyczne oraz częste nawroty po zaprzestaniu terapii, dlatego też niektórzy autorzy sugerują jej łączenie z innymi lekami bądź zmianę na inny lek (np. retinoid) po opanowaniu ostrej fazy choroby. Ze względu na potencjalne działanie onkogenne nie zaleca się łączenia z fototerapią. Stosując CsA u dzieci, należy pamiętać, że jako lek immunosupresyjny zmniejsza ona odporność poszczepienną. Przeciwwskazane są szczepionki zawierające żywe drobnoustroje, a przebieg chorób wirusowych charakterystycznych dla wieku dziecięcego może być cięższy [1, 8, 40,41].

Metotreksat (MTX) nie jest zalecany do stosowania u dzieci poniżej 3. roku życia. Na ogół wykorzystuje się go w krótkotrwałej terapii ciężkiej łuszczycy plackowatej, erytrodermii łuszczycowej oraz łuszczycowym zapaleniu stawów. Zazwyczaj jest lepiej tolerowany przez dzieci niż dorosłych. Zaletą jest sposób dawkowania jeden raz w tygodniu. Zastosowanie formy podskórnej leku ogranicza liczbę działań niepożądanych ze strony przewodu pokarmowego (nudności, wymioty). Poważne działania niepożądane obejmują hepatotoksyczność (u dzieci występującą znacznie rzadziej niż u dorosłych) [1, 10, 20, 36, 42], zwłóknienie płuc (u dzieci epizodyczne) oraz mielotoksyczność. Zaburzenia ze strony szpiku występują zazwyczaj w pierwszych 4-6 tygodniach terapii. $Z$ tego względu część autorów zaleca rozpoczynanie od dawki 1,25 mg i zwiększanie jej do $5 \mathrm{mg}$ przy dobrej tolerancji leczenia. Spośród licznych interakcji lekowych, w które wchodzi MTX, u dzieci największe znaczenie mają kojarzenie MTX z niesteroidowymi lekami przeciwzapalnymi (NLPZ) oraz trimetoprymem lub sulfametoksazolem [36, 37] (tab. 1).

\section{ESTRY KWASU FUMAROWEGO I APREMILAST}

Estry kwasu fumarowego (fumaric acid esters FAE) są lekami o działaniu immunomodulującym niezarejestrowanymi w Polsce. W Niemczech dostępne są ich preparaty stosowane w terapii łuszczycy plackowatej o umiarkowanym i dużym nasileniu [37]. Badania dzieci są nieliczne. Retrospektywna analiza 14 pacjentów leczonych FAE wykazała, że w 36\% przypadków doszło do całkowitej reemisji, w 7\% przypadków poprawa była istotna klinicznie, w 21\% jedynie częściowa, a u 36\% chorych stosowanie leku nie przyniosło efektu. Leczenie kontynuowano przez 
Table I. Non-biological agents used in treating childhood psoriasis (based on the summary of product characteristics, SmPC) [40, 4I] Tabela I. Leki ogólne niebiologiczne stosowane w leczeniu łuszczycy u dzieci (na podstawie charakterystyki produktu leczniczego, ChLP) [40, 4I]

\begin{tabular}{|c|c|c|c|}
\hline Drug/Lek & Dosing/Dawkowanie & $\begin{array}{c}\text { Tests before treatment/ } \\
\text { Badania przed wdrożeniem } \\
\text { terapii }\end{array}$ & $\begin{array}{c}\text { Treatment safety assessment/Ocena } \\
\text { bezpieczeństwa terapii }\end{array}$ \\
\hline $\begin{array}{l}\text { methotrexate/ } \\
\text { metotreksat }\end{array}$ & $\begin{array}{c}0.2-0.7 \mathrm{mg} / \mathrm{kg} \text { b.w; initial dose } \\
\text { I.25-5 mg/ } \\
\text { 0,2-0,7 mg/kg m.c.; dawka } \\
\text { początkowa I,25-5 mg }\end{array}$ & $\begin{array}{c}\text { blood count, renal and } \\
\text { hepatic function, viral hepatitis } \\
\text { types A, B, C, HIV; chest } \\
\text { X-ray/ } \\
\text { morfologia, parametry } \\
\text { nerkowe, wątrobowe, } \\
\text { wirusowe zapalenie wątroby } \\
\text { typu A, B, C, HIV; RTG klatki } \\
\text { piersiowej }\end{array}$ & $\begin{array}{l}\text { blood count, hepatic function once per week in } \\
\text { the first month, every } 2 \text { weeks for the next } \\
2 \text { months, once per month for the next } \\
3 \text { months, then every } 3 \text { months; renal function } \\
\text { - every } 6 \text { months/ } \\
\text { morfologia, parametry wątrobowe I raz na } \\
\text { tydzień przez pierwszy miesiąc, co } 2 \text { tygodnie } \\
\text { przez kolejne } 2 \text { miesiące, I raz na miesiąc przez } \\
\text { kolejne } 3 \text { miesiące, następnie co } 3 \text { miesiące; } \\
\text { funkcja nerek - co } 6 \text { miesięcy }\end{array}$ \\
\hline $\begin{array}{l}\text { cyclosporine A/ } \\
\text { cyklosporyna A }\end{array}$ & $\begin{array}{l}3-5 \mathrm{mg} / \mathrm{kg} \text { b.w./ } \\
3-5 \mathrm{mg} / \mathrm{kg} \text { m.c. }\end{array}$ & $\begin{array}{c}2 \times \text { creatinine measurement, } \\
\text { BP/ } \\
\text { 2-krotne oznaczenie } \\
\text { kreatyniny, RR }\end{array}$ & $\begin{array}{c}\text { creatinine control every } 2 \text { weeks for the first } \\
3 \text { months, then once per month; with } 30 \% \\
\text { increase, reduce dose by } 25 \% \text {; with } 50 \% \\
\text { increase, stop treatment; BP control on every } \\
\text { visit/ } \\
\text { kontrola kreatyniny co } 2 \text { tygodnie przez } \\
\text { pierwsze } 3 \text { miesiące, następnie I raz na } \\
\text { miesiąc; przy wzroście } 30 \% \text { zredukować } \\
\text { dawkę o } 25 \% \text {; przy wzroście o 50\% przerwać } \\
\text { terapię; kontrola RR przy każdej wizycie }\end{array}$ \\
\hline $\begin{array}{l}\text { acitretin/ } \\
\text { acytretyna }\end{array}$ & $\begin{array}{l}0.5-1 \mathrm{mg} / \mathrm{kg} \text { b.w./ } \\
0,5-1 \mathrm{mg} / \mathrm{kg} \text { m.c. }\end{array}$ & $\begin{array}{l}\text { hepatic function, lipid profile/ } \\
\text { funkcje wątroby, profil } \\
\text { lipidowy }\end{array}$ & $\begin{array}{l}\text { hepatic function and lipid profile every } 2 \text { weeks } \\
\text { for the first } 2 \text { months, then once every } 3 \text { months/ } \\
\text { funkcje wątroby i profil lipidowy co } 2 \text { tygodnie } \\
\text { przez } 2 \text { miesiące, następnie I raz na } 3 \text { miesiące }\end{array}$ \\
\hline
\end{tabular}

$B P$ - blood pressure.

$R R$ - ciśnienie tętnicze krwi.

uria, and increased serum creatinine concentration $[1,43]$. The treatment outcomes seem promising enough to warrant consideration of FAEs for treatment of psoriasis in children if MTX therapy is ineffective or contraindicated [1].

Another notable drug is apremilast, which has not, however, been approved yet for children, and thus its potential for use in this age group is uncertain. Apremilast is a phosphodiesterase (PDE4) inhibitor that affects intracellular signaling, thus inhibiting the synthesis of proinflammatory cytokines, including TNF, IL-12, and IL-23. It is used as second-line treatment in patients who did not respond to first-line treatment or could not be treated with MTX, retinoids, or cyclosporin. Researchers have found high effectiveness and good tolerance of apremilast in adult patients, though an adverse impact on the patients' psychological status and an increased number of suicides have also been reported. Smith reported beneficial effects of oral apremilast in a 14-year-old patient [44].

\section{BIOLOGICAL DRUGS}

Biological drugs are a fast-growing group of agents targeting specific inflammatory mediators. Based on the mechanism of action, biological drugs średnio 10 miesięcy (od 1 do 80 miesięcy w grupie badanej). Rozpoczynano od $30 \mathrm{mg}$ fumaranu dimetylu, w zależności od efektu oraz występowania lub braku objawów ubocznych zwiększano dawkę do osiągnięcia dawki maksymalnej (720 mg/dobę) [1, 43]. Zaobserwowane skutki uboczne preparatu obejmowały eozynofilię, okresowe zmiany liczby leukocytów, rumień, dolegliwości ze strony przewodu pokarmowego, w tym dysfunkcję wątroby objawiającą się wzrostem stężenia enzymów wątrobowych (aminotransferaz), jak również obecność proteinurii oraz zwiększenie stężeń kreatyniny w surowicy $[1,43]$. Efekt leczenia wydaje się na tyle obiecujący, że przy braku skuteczności lub niemożności wdrożenia innej terapii zasadne może być zastosowanie FAE w leczeniu łuszczycy u dzieci [1].

Należy wspomnieć również o apremilaście, niedawno zarejestrowanym $\mathrm{w}$ terapii łuszczycy $\mathrm{u}$ dorosłych. Apremilast jest inhibitorem fosfodiesteraz (phosphodiesterase 4 - PDE4), który wpływa na przekaźnictwo sygnałów wewnątrzkomórkowych, hamując syntezę cytokin prozapalnych, m.in. TNF, IL-12 i IL-23. Stosuje się go w leczeniu drugiego rzutu u pacjentów, u których nie uzyskano odpowiedzi na leki pierwszego rzutu lub u których nie można stosować MTX, retinoidów czy CsA. U dorosłych pacjentów leczonych apremilastem stwierdzono dobrą skuteczność przy bardzo dobrej tolerancji leku, chociaż pojawiły się informacje o nieko- 
are classified as TNF inhibitors (the largest group, including etanercept, adalimumab, infliximab), IL-12 and IL-23 antagonists (ustekinumab) [36, 40, 41, 45], or IL-17 antagonists (secukinumab, ixekizumab, brodalumab) [46].

So far, studies using this category of drugs have yielded very promising results. The products are highly effective and have rather good safety profiles. Currently, 3 biological drugs have been approved for treatment of psoriasis in children: etanercept, adalimumab (also for psoriatic arthritis in children), and ustekinumab. The IL-17 antagonist secukinumab is currently undergoing trials. Due to the high treatment cost, the drugs are restricted to a small group of patients with very severe disease, whose treatment is financed either by the Polish National Health Fund or under clinical trial programs operated by specialized institutions [38]. None of the biological drugs are recommended as first-line treatment, and the ineffectiveness of one drug of this category is not a contraindication for the use of another [38].

The mechanism of action of these biological drugs causes a decreased systemic immune response and may contribute to higher incidence of infections or activation of latent infections. (Before starting treatment, the existence of inflammatory foci and infections, e.g. with Mycobacterium tuberculosis, must be ruled out.) Due to its epidemiology, the potential reactivation of $\mathrm{HBV}$ is of less importance in children. A more significant factor is the potential impact of these drugs, altering immune system function, on the course and clinical presentation of childhood diseases. Adverse effects of these drugs include hypersensitivity reactions: topical, at the site of administration, and systemic, including anaphylactic shock. Children treated with biological drugs have a lower post-vaccination immunity, and vaccines containing viable pathogens are contraindicated in this group. Alarming reports of increased incidence of malignant tumors in patients treated with TNF inhibitors before the age of 18 warrant further research [41].

Biological drugs currently used for treatment of psoriasis in children include:

- Etanercept - a fusion protein. The drug for which most clinical data are available regarding use in children with psoriasis. Seems to have a very good effectiveness and safety profile [40,45];

- Adalimumab - a fully human monoclonal antibody. The only drug approved for both plaque psoriasis and psoriatic arthritis in children;

- Infliximab - a human and murine chimeric monoclonal antibody. Not registered for treatment of childhood psoriasis. Used off label, due to its very strong anti-TNF action, in cases resistant to rzystnym działaniu na stan psychiczny i zwiększonej liczbie samobójstw. Dotychczasowe doświadczenia ze stosowaniem leku u dzieci są incydentalne. Smith opisał korzystny efekt zastosowania apremilastu doustnie u 14-letniego dziecka [44].

\section{LEKI BIOLOGICZNE}

Leki biologiczne to dynamicznie rozwijająca się grupa leków działających w sposób celowany na poszczególne mediatory zapalne. Ze względu na mechanizm działania wśród leków biologicznych stosowanych w terapii łuszczycy wyróżnia się stanowiące największą grupę inhibitory TNF (etanercept, adalimumab, infliksymab), antagonistów IL-12 i IL-23 (ustekinumab) [36, 40, 41,45 ] oraz antagonistów IL-17 (sekukinumab, iksekizumab, brodalumab) [46].

Dotychczasowe wyniki badań z tą grupą leków są bardzo zachęcające. Produkty cechują się wysoką skutecznością i dość dobrym profilem bezpieczeństwa. Obecnie 3 z nich są zarejestrowane do leczenia łuszczycy u dzieci (etanercept, adalimumab - również w łuszczycowym zapaleniu skóry u dzieci, i ustekinumab). W trakcie badań jest antagonista IL-17 - sekukinumab. Ze względu na duże koszty leki te są zarezerwowane dla wąskiej grupy pacjentów z bardzo ciężkim przebiegiem choroby jako leczenie refundowane przez Narodowy Fundusz Zdrowia lub w ramach programów badań klinicznych w ośrodkach specjalistycznych [38]. Żaden z leków biologicznych nie jest rekomendowany jako lek pierwszego wyboru, a nieskuteczność jednego nie stanowi przeciwwskazania do zastosowania innego leku z tej grupy [38].

Leki biologiczne poprzez swój mechanizm działania zmniejszają odpowiedź immunologiczną organizmu i sprzyjają większej zapadalności na infekcje oraz aktywacji utajonych zakażeń (przed rozpoczęciem terapii należy wykluczyć obecność ognisk zapalnych oraz infekcji, np. Mycobacterium tuberculosis). Ze względów epidemiologicznych reaktywacja HBV u dzieci ma mniejsze znaczenie, bardziej istotny jest wpływ, jaki przez zmianę funkcjonowania układu immunologicznego leki te mogą wywierać na przebieg i obraz kliniczny chorób typowych dla wieku dziecięcego. Do działań niepożądanych tych leków należą reakcje nadwrażliwości: miejscowe w miejscu podania oraz ogólnoustrojowe ze wstrząsem anafilaktycznym włącznie. Dzieci leczone lekami biologicznymi cechuje niższa odpowiedź immunologiczna na szczepienia, a szczepionki zawierające żywe drobnoustroje są u nich przeciwwskazane. Niepokój budzą obserwacje dotyczące zwiększonej zapadalności na nowotwory złośliwe u osób, u których rozpoczęto terapię inhibitorami TNF przed ukończeniem 18. roku życia, dlatego konieczne są dalsze badania [41].

Obecnie stosowane leki biologiczne w terapii łuszczycy dziecięcej to: 
other biological drugs [41]. As a portion of the molecule is encoded by murine genes, there is a higher risk of hypersensitivity induction than with other drugs in the category. For this reason, the drug should only be administered in hospital settings [36];

- Ustekinumab - the latest monoclonal antibody registered for treatment of childhood psoriasis (interleukin-12/23 binding). Treatment with the drug is convenient due to its long action - subsequent doses are administered every 12 weeks;

- Secukinumab - an IL-17 antagonist, registered for treatment of plaque psoriasis in adults, clinical trials in children currently underway [47].

The latest research indicates that IL-22 might be a potential specific treatment target in children with psoriasis. Compared to adult psoriatic patients, pediatric patients displayed a different profile of expression of cytokines produced by CD4 and CD8 cells in the diseased tissue (significant increase in IL-22 and much lower increase in IL-17 levels). Unlike in adult patients, no increase in regulatory $\mathrm{T}$ cells was observed in children [48] (Table 2).

\section{SUMMARY}

Psoriasis in children poses significant problems in diagnosis and treatment. Early onset of psoriatic lesions may be associated with a risk of early development of complications, e.g. metabolic syndrome. Appropriate therapeutic interventions may prevent
- etanercept - białko fuzyjne; istnieje najwięcej danych klinicznych ze stosowania u dzieci z łuszczycą; wydaje się, że ma bardzo korzystny profil skuteczności i bezpieczeństwa $[40,45]$;

- adalimumab - w pełni ludzkie przeciwciało monoklonalne; jako jedyny ma rejestrację nie tylko w łuszczycy plackowatej, lecz także w ŁZS u dzieci;

- infliksymab - ludzko-mysie przeciwciało monoklonalne; nie ma rejestracji w leczeniu łuszczycy u dzieci, stosowany off-label ze względu na bardzo silny efekt anty-TNF $\mathrm{w}$ przypadkach opornych na inne leki biologiczne [41]. Ze względu na fakt, że część cząsteczki przeciwciała jest kodowana przez geny mysie, jest obarczony większym ryzykiem indukowania reakcji nadwrażliwości niż inne leki z tej grupy. Z tego też powodu powinien być podawany jedynie w warunkach szpitalnych [36];

- ustekinumab - najnowsze zarejestrowane w terapii łuszczycy dziecięcej przeciwciało monoklonalne wiążące IL-12/IL-23; wygodny w terapii ze względu na długi okres działania - kolejne dawki podaje się w odstępach 12- tygodniowych;

- sekukinumab - jeden z antagonistow IL-17, zarejestrowany w leczeniu łuszczycy plackowatej u dorosłych; u dzieci w trakcie badań klinicznych [47].

Ostatnie badania wskazują na IL-22 jako potencjalny, swoisty cel terapii u dzieci z łuszczycą. W grupie pediatrycznej zaobserwowano odmienny profil ekspresji cytokin wytwarzanych przez komórki CD4+ i CD8+ w zmienionej chorobowo tkance (znaczący wzrost stężenia IL-22 i o wiele mniejszy wzrost IL-17) w porów-

Table 2. Biological agents used in treating childhood psoriasis (based on the summary of product characteristics, SmPC) Tabela 2. Leki biologiczne stosowane w leczeniu łuszczycy u dzieci (na podstawie charakterystyki produktu leczniczego, ChPL)

\begin{tabular}{|c|c|c|c|}
\hline $\begin{array}{l}\text { etanercept/ } \\
\text { etanercept }\end{array}$ & $\begin{array}{l}\text { TNF inhibitor/ } \\
\text { anty-TNF }\end{array}$ & $\begin{array}{c}>6 \text { years old, plaque, } \\
>12 \text { years old, PsA } \\
>6 \text { lat, łuszczyca plackowata, } \\
>12 \text { lat, łuszczycowe zapalenie } \\
\text { stawów }\end{array}$ & $\begin{array}{c}0.8 \mathrm{mg} / \mathrm{kg} \text { b.w./week or } 0.4 \mathrm{mg} \text { twice per week/ } \\
0,8 \mathrm{mg} / \mathrm{kg} \mathrm{m} . \mathrm{c} . / \text { tydzień lub } 0,4 \mathrm{mg} 2 \text { razy na tydzień }\end{array}$ \\
\hline $\begin{array}{l}\text { adalimumab/ } \\
\text { adalimumab }\end{array}$ & $\begin{array}{l}\text { TNF inhibitor/ } \\
\text { anty-TNF }\end{array}$ & $\begin{array}{c}>4 \text { years old, plaque/ } \\
>4 \text { lat, łuszczyca plackowata }\end{array}$ & $\begin{array}{c}0.8 \mathrm{mg} / \mathrm{kg} \text { b.w. (up to max } 40 \mathrm{mg} \text { ) in I-week intervals, } \\
\text { then every } 2 \text { weeks/ } \\
\text { 0,8 mg/kg m.c. (do } 40 \mathrm{mg} \text { maks.) w odstępie } \\
\text { I tygodnia, następne dawki co } 2 \text { tygodnie }\end{array}$ \\
\hline $\begin{array}{l}\text { ustekinumab/ } \\
\text { ustekinumab }\end{array}$ & $\begin{array}{l}\text { IL- } 12 \text { and IL-23 inhibitor/ } \\
\text { anty-IL- } 12 \text { i anty-IL-23 }\end{array}$ & $\begin{array}{c}>12 \text { years old, plaque/ } \\
>12 \text { lat, łuszczyca plackowata }\end{array}$ & $\begin{array}{c}0.75 \mathrm{mg} / \mathrm{kg} \text { b.w. for patients }<60 \mathrm{~kg} \text {, if }>60 \text { dose as } \\
\text { in adults; second dose after } 4 \text { weeks, then every } \\
\text { I } 2 \text { weeks/ } \\
0,75 \mathrm{mg} / \mathrm{kg} \text { m.c. dla pacjentów }<60 \mathrm{~kg} \text {, } \\
\text { jeśli }>60 \mathrm{~kg} \text {, jak dla dorosłych; druga dawka } \\
\text { po } 4 \text { tygodniach, następne co I } 2 \text { tygodni }\end{array}$ \\
\hline $\begin{array}{l}\text { infliximab/ } \\
\text { infliksymab }\end{array}$ & $\begin{array}{l}\text { TNF inhibitor/ } \\
\text { anty-TNF }\end{array}$ & $\begin{array}{c}>6 \text { years old in Crohn's disease } \\
\text { and C. ulcerosa, in childhood } \\
\text { psoriasis off label/ } \\
>6 \text { lat w chorobie } \\
\text { Leśniowskiego-Crohna } \\
\text { i C. ulcerosa, w łuszczycy u dzieci } \\
\text { off-label }\end{array}$ & $\begin{array}{c}3-5 \mathrm{mg} / \mathrm{kg} \text { b.w., 0.6/week, then every } 8 \text { weeks/ } \\
3-5 \mathrm{mg} / \mathrm{kg} \text { m.c. w tyg. 0,6, następnie co } 8 \text { tygodni }\end{array}$ \\
\hline
\end{tabular}


or reduce the adverse consequences of these complications. Further studies are warranted, assessing the course of psoriasis, its complications, and most of all, the effectiveness of treatment.

\section{CONFLICT OF INTEREST}

The authors declare no conflict of interest. naniu z dorosłymi pacjentami. W przeciwieństwie do dorosłych u dzieci nie wystąpił wzrost liczby limfocytów T regulatorowych [48] (tab. 2).

\section{PODSUMOWANIE}

Łuszczyca u dzieci jest istotnym problemem diagnostyczno-terapeutycznym. Wczesne wystąpienie zmian łuszczycowych może się wiązać z ryzykiem przedwczesnego rozwoju powikłań, np. zespołu metabolicznego. Odpowiednio dobrane interwencje terapeutyczne mogą zapobiec lub zmniejszyć niekorzystne konsekwencje tych powikłań. Ważne jest prowadzenie dalszych badań w celu oceny przebiegu łuszczycy, jej powikłań, a przede wszystkim skuteczności wdrażanych terapii.

\section{KONFLIKT INTERESÓW}

Autorzy deklarują brak konfliktu interesów.

\section{References}

\section{Piśmiennictwo}

1. Bronckers I., Paller A.S., van Geel M.J., van Kerkfof P., Seyger M.: Psoriasis in children and adolescents: diagnosis, management and comorbidities. Pediatr Drugs 2015, 17, 373-384.

2. Shah K.N.: Diagnosis and treatment of pediatric psoriasis: current and future. Am J Clin Dermatol 2013, 14, 195-213.

3. Parisi R., Symmons D.P., Griffiths C.E, Ashcroft D.M.: Identification and Management of Psoriasis and Associated ComorbidiTy (IMPACT) project team: global epidemiology of psoriasis: a systematic review of incidence and prevalence. J Invest Dermatol 2013, 133, 377-85.

4. Gliński W., Wolska H.: Zasady postępowania w łuszczycy. Consensus PTD. Przegl Dermatol 2000, 87, 465-471.

5. Tollefson M.M., Cynthia S.C., McEvoy M.T., Maradit Kremers H.: Incidence of psoriasis in children: a population-based study. J Am Acad Dermatol 2010, 62, 979-987.

6. Burden-Teh E., Thomas K.S., Ratib S., Grindlay D., Adaji E., Murphy R.: The epidemiology of childhood psoriasis: a scoping review. Br J Dermatol 2016, 174, 1242-1257.

7. Mercy K., Kwasny M., Cordoro K.M., Menter A., Tom W.L., Korman N., et al.: Clinical manifestations of pediatric psoriasis: results of a multicenter study in the United States. Pediatr Dermatol 2013, 30, 424-428.

8. Mahe E.: Child psoriasis. Eur J Dermatol 2016, 26, 537-548.

9. Augustin M., Glaeske G., Radtke M.A., Christophers E., Reich K., Schafer I.: Epidemiology and comorbidity of psoriasis in children. Br J Dermatol 2010, 162, 633-636.

10. Benoit S., Hamm H.: Childhood psoriasis. Clin Dermatol 2007, 25, 555-562.

11. Schafer T.: Epidemiology of psoriasis. Review and the German perspective. Dermatology 2006, $212,327-37$.

12. Kosmala A., Jenerowicz D., Adamski Z.: Opis przypadku łuszczycy pospolitej u sióstr - domniemana rola czynników genetycznych, zakaźnych oraz stresu w powstawaniu choroby. Dermatol Prakt 2016, 3, 53-58.

13. Paller A.S., Mercy K., Kwasny M.J., Choon S.E., Cordoro K.M., Girolomoni G., et al.: Association of pediatric psoriasis severity with excess and central adiposity. JAMA Dermatol 2013, 149, 166-176.

14. Flisiak I.: Komentarz. [Dogra S., Kaur I.: Łuszczyca wieku dziecięcego. Dermatol Dypl 2012, 3, 37-46]. Dermatol Dypl 2012, 3, 47-48.

15. Chwała C., Buczyłko K., Wagner A.: Pojawienie się objawów łuszczycy w trakcie odczulania alergenową szczepionką podjęzykową - opis przypadku. Alerg Astma Immunol 2010, 15, 53-55.

16. Murphy M., Kerr P., Grant-Kels J.M.: The histopathologic spectrum of psoriasis. Clin Dermatol 2007, 25, 524-528.

17. Haliasos E., Kerner M., Jaimes-Lopez N., Rudnicka L., Zalaudek I., Malvehy J., et al.: Dermoscopy for the pediatric dermatologist part I: dermoscopy of pediatric infectious and inflammatory skin lesions and hair disorders. J Pediatr Dermatol 2013, 30, 163-171.

18. Matusiewicz D., Koerber A., Schadendorf D., Wasem J., Neumann A.: Childhood psoriasis - an analysis of German health insurance data. Pediatr Dermatol 2014, 31: 8-13.

19. Liao P.B., Rubinson R., Howard R., Sanchez G., Frieden I.J.: Annular pustular psoriasis-most common form of pustular psoriasis in children: report of three cases and review of the literature. Pediatr Dermatol 2002, 19, 19-25.

20. Dogra S., Kaur I.: Childhood psoriasis. Indian J Dermatol Venereol Leprol 2010, 76, 357-365.

21. Pourchot D., Bodemer C., Phan A., Bursztejn A.C., Hadj-Rabia S., Boralevi F., et al.: Nail psoriasis: a systematic evaluation in 313 children with psoriasis. Pediatr Dermatol 2017, 34, 58-63.

22. Bonigen J., Phan A., Hadj-Rabia S., Boralévi F., Bursztejn A.C., Bodemer C., et al.: Impact of sex and age on the clinical and epidemiological aspects of childhood psoriasis: data from a French cross-selectioned multicentre study. Ann Dermatol Venereol 2016, 143, 354-363. 
23. Hagiwara K., Suyama Y., Fukuda K.: Clinical experience in 115 patients with arthritis and/or enthesitis who met the classification criteria for psoriatic arthritis (CASPAR) within the last two years-possible association with malignant disorders. Mod Rheumatol 2016, 26, 625-629.

24. Tollefson M.M., Finnie D.M., Schoch J.J., Eton D.T.: Impact of childhood psoriasis on parents of affected children. J Am Acad Dermatol 2017, 76, 286-289.

25. Farnik M., Brozek G., Pierzchala W., Zejda J.E., Skrzypek M., Walczak L.: Development, evaluation, and validation of a new instrument for measurement quality of life in the parents of children with chronic disease. Health Qual Outcomes $2010,8,151$.

26. Devrimci-Ozguven H., Kundakci T.N., Kumbasar H., Boyvat A.: The depression, ankiety, life satisfaction and affective expression levels in psoriasis patients. J Eur Acad Dermatol Venereol 2000, 14, 267-271.

27. Kimball A.B., Wu E.Q., Guerin A., Yu A.P., Tsaneva M., Gupta S.R., et al.: Risks of developing psychiatric disorders in pediatric patients with psoriasis. J Am Acad Dermatol 2012, 67, 651-7.e1-2.

28. Zhu K.J., He S.M., Zhang C., Yang S., Zhang X.J.: Relationship of the body mass index and childhood psoriasis in a Chinese Han population: a hospital-based study. J Dermatol 2012, 39, 181-183.

29. Naldi L., Mercuri S.R.: Epidemiology of comorbidities in psoriasis. Dermatol Ther 2010, 23, 114-118.

30. Pietrzak A., Grywalska E., Walankiewicz M., Lotti T., Roliński J., Myśliński W.: Psoriasis and metabolic syndrome in children: current data. Clin Exp Dermatol 2017, 42, 131-136.

31. Au S.C., Goldminz A.M., Loo D.S., Dumont N., Levine D., Volf E., et al.: Association between pediatric psoriasis and the metabolic syndrome. J Am Acad Dermatol 2012, 66, 1012-1013.

32. Koebnick C., Black M.H., Smith N., Der-Sarkissian J.K., Porter A.H., Jacobsen S.J.: The association of psoriasis and elevated blood lipids in overweight and obese children. J Pediatr 2011, 159, 577-83.

33. Volf E.M., Levine D.E., Michelon M.A., Au S.C., Patvardhan E., Dumont N., et al.: Assessor-blinded study of the metabolic syndrome and surrogate markers of increased cardiovascular risk in children with moderate-to-severe psoriasis compared with age-matched population of children with warts. J Drugs Dermatol 2011, 10, 900-901.

34. Tom W.L., Playford M.P., Admani S., Natarajan B., Joshi A.A., Eichenfield L.F., et al.: Characterization of lipoprotein composition and function in pediatric psoriasis reveals a more atherogenic profile. J Invest Dermatol 2016, 136, 67-73.

35. Tollefson M.M.: Diagnosis and management of psoriasis in children. Pediatr Clin North Am 2014, 61, $261-277$.

36. Fotiadou C., Lazaridou E., Ioannides D.: Management of psoriasis in adolescence. Adolesc Health Med Ther 2014, 5, $25-34$.

37. Pathirana D., Ormerod A.D., Saiag P., Smith C., Spuls P.I., Nast A., et al.: European S3-guidelines on the systemic treatment of psoriasis vulgaris. J Eur Acad Dermatol Venereol 2009, 23, 1-70.

38. Szepietowski J., Adamski Z., Chodorowska G., Gliński W., Kaszuba A., Placek W., et al.: Leczenie łuszczycy zwyczajnej - rekomendacje ekspertów Polskiego Towarzystwa Dermatologicznego. Część I: łuszczyca łagodna, łuszczyca wieku dziecięcego. Diagnostics and treatment of psoriasis vulgaris: guidelines of the Polish Dermatological Society. Part I: mild psoriasis, psoriasis in children. Przegl Dermatol 2012, 99, 83-96.

39. Rosińska-Borkowska D.: Komentarz. [Sticherling M., Augustin M., Boehncke W.H., Christophers E., Domm S., Gollnick H., et al.: Terapia łuszczycy w okresie dzieciństwa i dojrzewania - konsensus niemieckich ekspertów. Dermatol Kosmetol Prakt 2011, 6, 8-19]. Dermatol Kosmetol Prakt 2011, 6, 19-20.

40. Napolitano M., Megna M., Balato A., Ayala F., Lembo S., Villani A., et al.: Systemic treatment of pediatric psoriasis: a review. Dermatol Ther 2016, 6, 125-142.

41. Marqueling A.L., Cordoro K.M.: Systemic treatments for severe pediatric psoriasis: a practical approach. Dermatol Clin 2013, 31, 267-288.

42. Hashkes P.J., Becker M.L., Cabral D.A., Laxer R.M., Paller A.S., Rabinovich C.E., et al.: Methotrexate: new uses for an old drug. J Pediatr 2014, 164, 231-236.

43. Balak D.M., Oostveen A.M., Bousema M.T., Venema A.W., Arnold W.P., Seyger M.M., et al.: Effectiveness and safety of fumaric acid esters in children with psoriasis: a retrospective analysis of 14 patients from The Netherlands. Br J Dermatol 2013 , 168, 1343-1347.

44. Smith R.L.: Pediatric psoriasis treated with apremilast. JAAD Case Rep 2016, 2, 89-91.

45. Pietrzak A., Grywalska E., Walankiewicz M., Roliński J., Szepietowski J., Chodorowska G.: Łuszczyca pospolita wieku dziecięcego - leczenie biologiczne etanerceptem. (Psoriasis vulgaris in children - biological treatment with etanercept). Dermatol Dziec 2014, 4, 73-77.

46. Wasilewska A., Winiarska M., Olszewska M., Rudnicka L.: Interleukin-17 inhibitors. A new era in treatment of psoriasis and other skin diseases. Adv Dermatol Allergol 2016, 33, 247-252.

47. Relvas M., Torres T.: Pediatric psoriasis. Am J Clin Dermatol 2017 May 24. doi: 10.1007/s40257-017-0294-9 [Epub ahead of print].

48. Cordoro K.M., Hitraya-Low M., Taravati K., Sandoval P.M., Kim E., Sugarman J., et al.: Skin-infiltrating, interleukin-22-producing $T$ cells differentiate pediatric psoriasis from adult psoriasis. J Am Acad Dermatol 2017, 77, 417-424.

Received: 1.06 .2017

Accepted: 17.07 .2017

Otrzymano: $1.06 .2017 \mathrm{r}$

Zaakceptowano: 17.07.2017 r.

How to cite this article

Piekarska-Myślińska D., Pietrzak A., Myśliński W., Pietrzak D., Borysowicz M., Socha M., Krasowska D.: Childhood psoriasis. Dermatol Rev/Przegl Dermatol 2017, 104, 363-376. DOI: https://doi.org/10.5114/dr.2017.69944. 